Abant Tıp Dergisi

Araştırma Makalesi / Cilt 10 Sayı 3 Yıl 2021
Abant Medical Journal

Research Article / Volume 10 Issue 3 Year 2021

\title{
Hastaların Akılcı İlaç Kullanımına Yönelik Bilgi ve Davranışları
}

Information and Behavior of Patients about Rational Drug Use

Sema ORAL

Sağlık Bilimleri Üniversitesi Bursa Yüksek İhtisas Eğitim ve Araştırma Hastanesi, Bursa, Türkiye

Öz

GíRiş ve AMAÇ: Akılcı ilaç kullanımı (AiK); kişilerin klinik bulgularına ve bireysel özelliklerine göre uygun ilacı, uygun süre ve dozda, en uygun maliyetle ve kolayca sağlayabilmeleridir. Topluma yapılacak müdahalelerin daha etkin ve yerinde olabilmesinin en gerçekçi yolu, hastaların bu konudaki bilinç düzeylerinin ve yaklaşımlarının bilinmesidir. $\mathrm{Bu}$ çalışmanın amacı; hastaların Aik hakkındaki bilgi ve davranışlarının ortaya koyularak, gerekli önlemlerin alınması için bilimsel verilerin sunulmasıdır.

YÖNTEM ve GEREÇLER: Kesitsel tipte, tanımlayıcı nitelikte olan bu araştırma, 2018 yılının Nisan ve Mayıs aylarında, Sağıık Bilimleri Üniversitesi Bursa Yüksek İhtisas Eğitim ve Araştırma Hastanesi'nde yatmakta olan hastalarla anket çalışması olarak ( $n=152$ ) yapıldı.

BULGULAR: Hastaların hastalık durumunda \%91.6'sının doktora başvurduğu, kendi kendine başlanan ilaçların başında analjezikler (\%71.7) geldiği, tedavisini hekiminin önerdiği sürede kullananların oranının \%43.4 olduğu, hastaların \%67.8'inin eşdeğer ilacı kabul etmediği, \%20'sinin tedaviden arta kalan ilaçlarını çöpe attıkları ve \%63.6'sının evlerinde hiç kullanılmamış veya yarım kalmış en az 1 kutu ilaç bulundurdukları, \%4.1'inin basında reklamı yapılan ilaç dışı tedavi ürünlerini direk kullanabilecekleri, \%30'unun vitamin ve mineral desteği aldığı sonuçları ortaya koyulmuştur.

TARTIŞMA ve SONUÇ: Bu çalışmanın sonucunda hasta kaynaklı Aik ile ilgili parametrelerin bazılarının düzelme eğiliminde olmasına rağmen hala birçok hatalı davranışların olduğu gösterilmiştir. Aík hasta merkezli yaklaşımın benimsenmesi için ortaya koyulan bu veriler eksiklerin düzeltilmesi için katkı sağlayacaktır.

\section{Abstract}

INTRODUCTION: The rational use of drugs (RUD) requires that, patients receive medications appropriate to their clinical needs in doses that meet their own individual requirements for an adequate period of time and at the lowest cost. The most realistic way of making interventions to society more effective and appropriate is to know the awareness levels and approaches of the patients on this issue. The purpose of this study is; it is the presentation of scientific data in order to take necessary precautions by revealing the knowledge and behavior of patients about RUD.

METHODS: This cross-sectional, descriptive study was conducted in 2018 as a survey study with patients ( $n=152$ ) hospitalized at the University of Health Sciences Bursa Yuksek Ihtisas Training and Research Hospital.

RESULTS: This study reveals the following: $91.6 \%$ of the patients applied to a doctor in case of illness; analgesics (71.7\%) were the leading drugs without recipe; who used their treatment within the period recommended by the physician the rate was $43.4 \% ; 67.8 \%$ of the patients did not accept the equivalent drug; $20 \%$ of patients throw away their remaining medication from the treatment to trash and $63.6 \%$ of them had at least 1 box of unused or unfinished drugs at home; $4.1 \%$ of the patients could directly use nondrug treatment products advertised in the press, and $30 \%$ used vitamin and mineral support.

DISCUSSION and CONCLUSION: As a result of this study, it has been shown that although some of the RUD parameters related to the patient tend to improve, there are still many erroneous behaviors. These data, which are put forward for the adoption of the RUD patient-centered approach, will contribute to correcting the deficiencies.

\section{Giriş}

Dünya Sağlık Örgütü (DSÖ) akılcı ilaç kullanımı (Aik)'nı “kişilerin klinik bulgularına ve bireysel özelliklerine göre uygun ilacı, uygun süre ve dozda, en uygun maliyetle ve kolayca sağlayabilmeleri" olarak tanımlamaktadır (1).
AiK'de sorumlu taraflar arasında; hangi ilacın kullanılacağına karar veren hekim, ilacı uygun şartlarda sağlayan eczacı, ilacı uygulayan hemşire ve diğer sağlık personeli, hasta/hasta yakını, ilaç sektörü, düzenleyici otoriteler, meslek örgütleri, medya, akademik kuruluşlar gibi birçok kişi ve kurum yer almaktadır. Aik bileşenlerinden biri 
olan 'hasta'ların; Aik ilkeleri doğrultusunda sağlık hizmetinden yararlanmaları, en önemli hasta haklarından biridir (2).

Akılcı olmayan ilaç kullanımı (AOiK) tüm dünyada ciddi bir sorundur (3). DSÖ, dünya genelinde ilaçların \%50'sinden fazlasının uygun olmayan biçimde reçete edildiğini, hazırlandığını veya satıldığını; hastaların yarısından fazlasının da ilaçlarını doğru olmayan şekilde kullandığını bildirmiştir (4). AOik birçok nedene bağlı olabilmektedir (Tablo 1). AOіK; tedavi başarısızlığına, ciddi ilaç etkileşimlerine, yüksek toksisite insidansına, hastaların tedaviye uyumlarının azalmasına, hastalıkların tekrarlamasına veya uzamasına, advers olayların görülme sıklıklarının artmasına, antimikrobiyal direncin geliş̧mesine, bazı ilaçlara karşı bağımlııı gelişmesine, tedavi maliyetlerinin artmasıyla hastaların ve toplumun zarar görmesinin yanı sıra mevcut kaynakların israfına neden olmaktadır (2, $5,6)$.

İlaç kullanımı sağıık sistemi verimliliğinde kritik bir faktördür. Dünyada ilaç harcamaları, tüm sağlık harcamalarının beşte birini, hatta bazı ülkelerde daha fazlasını kullanmaktadır (7). Türkiye'de 2019 yılında toplam sağlık harcamalarının gayri safi yurtiçi hâsıla (GSYH)'ya oranı \%4.7'tür (8). Türkiye'de ilaç harcamaları, toplam sağlık harcamalarının \%25'inin üzerinde olmasından dolayı ilaç maliyetleri, sağlık harcamalarının önemli bir payına sahiptir (9). Uygunsuz ilaç harcamaları, Türkiye gibi gelişmekte olan ülkelerin ekonomisine ağır bir yük oluşturmaktadır (10).

Türkiye'deki hastanelerde bulunan 'hastane akılcı ilaç kullanımı ekibi'ne Aik konusunda önemli görevler düşmektedir. Bilinçli ilaç tüketimi konusundaki en önemli görev hastane klinik farmakologlarının üzerinde olmalıdır. AOiK'deki hasta kaynaklı sorunların net bir şekilde ortaya koyulması gerekmektedir. Topluma yapılacak müdahalelerin daha etkin ve yerinde olabilmesinin en gerçekçi yolu, hastaların bu konudaki bilinç düzeylerinin ve yaklaşımlarının bilinmesidir. Bu nedenle, bu çalışmanın amacı; hastaların akılcı ilaç kullanımı hakkındaki bilgi ve davranışlarının ortaya koyularak, gerekli önlemlerin alınması için bilimsel verilerin sunulmasıdır.

\section{GEREÇ ve YÖNTEMLER}

\section{Araştırmanın Tasarımı ve Örneklem}

Kesitsel tipte, tanımlayıc nitelikte olan bu araştırma, 2018 yılının Nisan ve Mayıs aylarında Sağlık Bilimleri Üniversitesi Bursa Yüksek İhtisas Eğitim ve Araştırma Hastanesi'nde yapıldı. Araştırma örneklemi olarak hastanenin yatılı servislerinde yatan tüm erişkin hastalara ulaşııldı. Anket formu dağıtılıp doldurmaları istendi. Ancak hatalı, eksik veya gönüllü olmayanlar çalışma dışı bırakıldı.

Anketteki sorular Türkiye İlaç ve Tıbbi Cihaz Kurumunun 'hastane yatan hasta anketi' örnek alınarak araştırmacı tarafından oluşturuldu. Ankette toplamda 34 soru yer aldı. Anketler katılımcıların cevaplarken araştırmacıdan etkilenmemeleri için dağıtılıp, cevaplandıktan sonra toplandı.

Anket formunun başına anketin yapılma nedenini anlatan bir metin eklendi. Ankete isimler kaydedilmedi. Anketin ilk 3 sorusu katılımcıların sosyodemografik özelliklerini yansıtıcı nitelik taşımaktaydı, diğer sorular katılımcıların Aik hakkında bilgi ve davranışları ile ilgili sorulardı. Buna göre; hastaların kendi kendini tedavi etme yaklaşımı, hastalık durumundaki davranışları, evdeki ilaçlarla ilgili bilgi ve davranışları, hastahekim ilişkisi, hasta-eczacı ilişkisi, ilaç dışı tedavi yaklaşımları, ilaç yan etkisine karşı yaklaşımları gibi konulardaki sorularla bilgi ve davranışları sorgulandı.

\section{Etik}

Araştırmanın etik onayı, Sağlık Bakanlığı Bursa Yüksek ihtisas Eğitim ve Araştırma Hastanesi Klinik Araştırmalar Etik Kurulu'ndan 2015/06-07 
karar numarasıyla alındı. Çalışmaya katılmayı kabul eden her katılımcıdan (n:152) 'bilgilendirilmiş gönüllü olur formu' onamı alındı. Çalışma Helsinki Bildirgesi ilkelerine uygun olarak gerçekleştirildi.

\section{İstatistiksel Analiz}

Araştırmadan elde edilen veriler elektronik ortama aktarıldı. Tanımlayıcı istatistiksel analizler frekans tabloları, grafikler, aritmetik ortalama ve standart sapmalar kullanılarak gösterildi. İki değişkenli tablolarda değişkenler arası ilişkiler Kikare bağımsızlık analizi ile incelendi. İstatistiksel anlamlılık düzeyi $p<0.05$ olarak kabul edildi.

\section{BULGULAR}

Çalışmaya katılan 152 katılımcının yaşı 18 ile 85 yaş aralığında olup, yaş ortalaması $45.8 \pm 18.6^{\prime}$ dır. Katılımcıların \%61.2 (n=93)'sini kadınlar oluşturmaktadır. Katılımcıların yarısından fazlası ilköğretim mezunu olup ( $n=87 ; \% 58.4$ ); hiçbiri yüksek lisans ya da doktora mezunu değildir (Tablo 2).

Katılımcıların \%91.6 ( $n=131)$ gibi yüksek bir oranı hastalık durumunda doktora gittiklerini belirtmiştir (Tablo 3). Katılımcıların kendi kendini tedavi etme yaklaşımlarında; grip, nezle, soğuk algınlığında muayene olmadan antibiyotik başlama oranları \%23.2 (n=33)'dir. Hastalık durumunda hekime muayene olmadan eczaneden ilaç alanlar \%17.7 ( $n=26)$, hasta olmadan ilaç satın alıp evde bulundurma oranı ise \%14.8'dir. Gerekli olabileceği düşüncesiyle hekime ilaç yazdırma oranı \%10.6 ( $n=15)^{\prime}$ 'dır. Komşularının ya da yakınlarının tavsiyesiyle ilaç kullananlar \%9.1 olmasına rağmen; benzer şikayetleri olan yakınlarına ilaç tavsiye ettiğini belirtenler \%17.6'dır. Yine yakınlarının tavsiye ettiği ilacı hekimden reçete etmesini isteme oranı da \%22.5'dir ( $n=32$ ). Kişiler analjezik intiyaçları olduğunda reçetesiz eczaneden alma oranı \%23.8 iken, eczane dışında bir yerden temin etme oranı ise \%2.7'dir. Hastaların \%4.1'i basında reklamı yapılan ilaç dışı tedavi ürünlerini direk kullanabileceğini, \%15.1'i hekime danışarak kullanabileceğini belirtmektedir. Katılımcıların vitamin, mineral desteği alıp almadıkları sorgulandığında, kendini kötü hissettiğinde kullananların oranı \%13.3 olmakla birlikte, en az ayda 3-4 kezden-her gün düzenli olarak alanlar toplamda \%30 oranındadır (Tablo 4).

Hastaların kendi kendine başladıkları ilaçlara bakıldığında analjezikler (\%71.7; n=38) en başta; ikinci sırada ise antibiyotikler (\%30.2; $n=16$ ) gelmektedir. Soğuk algınlığı ilaçları, merhemler, mide koruyucular ve antihipertansifler bu sırayı takip etmektedir (Grafik 1).

Katılımcıların evdeki ilaçlara karşı bilgi ve davranışlarına bakıldığında; \%94'ü bir ilacı kullanmadan önce son kullanma tarihini kontrol ettiğini belirtmektedir. Son kullanma tarihi geçtiği için kutusu dahi açılmadan en az 1 kutu ilacı attığını belirtenlerin oranı \%42.2'dir. Aile bireylerinin tedavi sonrası arta kalan ilaçlarını katılımcıların \%34.2'si (n=53) bir sağlık kuruluşuna verdiğini, \%28.3'ü $(n=44)$ gerektiği zaman kullanmak üzere sakladığını, \%20'si ( $n=31$ ) çöpe attığını belirtmektedir. Katılımcıların \%63.6'sı (n=94) evinde hiç kullanılmamış veya yarım kalmış en az 1 kutu ilaç bulunduğunu belirtmektedir. Ev içerisinde ilaçların saklanmasıyla ilgili bilgi ve davranışlarına bakıldığında; hastaların \%51.4'ü buzdolabında, $\% 45.9^{\prime} u$ ise oda sıcaklığında serin ve kuru bir yerde sakladığını belirtmektedir. Yine buzdolabında saklanması gereken ilaçları da büyük bir oranı buzdolabının kapağında sakladığını işaretlemiştir. Evde bulunan bir ilacı tekrardan kullanmak istediklerinde nelere dikkat ettiklerine dair davranışlarında ise katılımcılar, \%78.3 oranında son kullanma tarihlerinin dolmamış olmasına, \%69.2 oranında hastalığa uygunluğuna baktığını belirtmektedir. Evde bulunan ilaçları tekrardan kullanmak istediklerinde ise \%19.4'ü ( $n=28$ ) kimseden bilgi almadan kullandığını ifade etmektedir (Tablo 5).

Aik hasta-hekim arasındaki ilişkiye dair olan 
verilere bakıldığında; hastaların sadece \%7'si hekimini kullanmış olduğu ilaçlar hakkında bilgilendirdiğini, \%7.5'i ise besin ve ilaç alerjisi bilgilerini hekimi sorduğunda söylediğini belirtmektedir. Hekiminin verdiği reçeteyi hekimin önerdiği sürede kullanma oranı \%43.4 $(n=62)$ 'tür. Kontrol muayenesine gitme oranında; \%44.9 şikayetleri geçmez ise gittiğini belirtmektedir. Hastaların \%70.8'i ilacın enjektabl formunun daha iyi tedavi ettiğini düşünmektedir (Tablo 6).

Aik hasta-eczacı ilişkisinde; hastalar reçeteli ilaçlarını eczaneden alırken, \%24.8'i reçetede yazan ilaç olup olmadığını kontrol etmekte; $\% 67.8^{\prime} i$ eşdeğer ilacı kabul etmemektedir. Hastaların \%90.3'ü, eczacının verilen ilacı nasıl kullanılacağını yeterli ölçüde anlattıklarını düşünmektedir (Tablo 7).

Katılımcılar, ilacın kullanımı ve olası yan etkileriyle ile ilgili bilgileri en fazla ilaç prospektüsünden öğrenmektedirler (\%46.6; $\mathrm{n}=68$ ). İlacın yan etkileri ile karşılaşma durumunda ise hastalar \%83.4 oranında hekime başvuracaklarını belirtmektedir. Katılımcıların \%36.9'u sağlık personelinin ilaçlarla birlikte tüketilmemesi gereken yiyecek ve içecekler ile ilgili bilgilendirme yapmadığını belirtmektedir (Tablo 8).

Yaş, cinsiyet ve eğitim durumu gibi sosyodemografik özelliklerin akılcı ilaç kullanımına olan etkisi Tablo 9'da yer almaktadır. Grip, nezle, soğuk algınlığı gibi şikayetleri üzerine muayene olmadan, antibiyotik kullanma durumunda ve hasta olmadan ilaç satın alıp evde bulundurma durumlarında bireylerin yaş grupları ve cinsiyet farklılıkları arasında anlamlı ilişki saptanmamıştır. Ancak eğitim durumu ilişkisinde anlamlı farklılık bulunmuştur. Hastalık durumunda hekime başvurma davranışları, hastalıkta hekime muayene olmadan ilaç başlama, hasta olmadan ilaç yazdırma, tedavi sonrası kontrole gitme ve düzenli vitamin, mineral desteği alma alışkanlıklarında yaş, cinsiyet ve eğitim durumuna göre istatistiksel açıdan anlamlı bir ilişki bulunmamaktadır.

\section{TARTIŞMA}

Bu çalışmada hastaların akılcı ilaç kullanımı hakkındaki bilgi ve davranışları araştırılmaya çalışımıştır. Akılcı olmayan ilaç kullanımında karşılaşılan en önemli problemlerden biri, hastanın kendi kendini tedavi etme yaklaşımıdır (11). Yapılan çalışmalarda kişilerin hastalık durumunda hekime başvurmadan kendi kendini tedavi etme yaklaşımlarının genellikle $\% 60$ 'ın üzerinde olduğu vurgulanmaktadır $(12,13)$. Bu çalışmada hastaların, hastalık durumunda öncelikli olarak hekime başvurma oranının yüksekliği (\%91.6) ve muayene olmadan ilaç alıp başlama oranının (\%17.7) ise düşük olmasından dolayı; diğer çalışmalara göre kendi kendini tedavi etme yaklaşımlarının daha düşük olduğu söylenebilir. Bir başka gösterge olan hekim yazmadan antibiyotik başlama oranının üniversite öğrencileriyle yapılan bir çalışmada \%36.9 (10) olmasına rağmen, bu çalışmada \%23.2 olarak hesaplanmıştır. Bu durum, daha eğitimlilerin Aik bakımından daha olumsuz özelliklere sahip oldukları bilgisiyle uyumlu olabileceği bilgisiyle açıklanabilir $(12,14,15,16)$. Çünkü bu çalışmadaki katılımcıların büyük bir kısmı ilköğretim mezunu olup, üniversite mezunu olanların oranı çok düşüktür. Bir başka bakış açısıyla; çalışmamızdaki kendi kendini tedavi etme yaklaşımının daha iyi bir durumda olması belki de yürütülen Aik politikalarının işe yararlılı̆ı olarak da değerlendirilebilir (17).

Ülkemizde sınırlı sayıda ilaç hariç çoğu ilaç reçeteli alınmak zorundadır. Ancak gerek yasal bazı düzenlemelerin eksiklikleri, gerekse toplumun bu konudaki bilinçsiz davranışlarından dolayı hala reçetesiz ilaç kullanımı ciddi bir AOik sorunudur. Çalışmada en fazla reçetesiz alınan ilaçların başında analjezikler gelmektedir. Çoğu zaman hastalar analjezikleri ciddi bir ilaç olarak görmemektedirler (18). Oysaki analjeziklerin yanlış kullanımıyla toksik etkiler sık görülmektedir 
(19). Analjeziklerden sonra ikinci en sık reçetesiz kullanılan ilaçlar antibiyotiklerdir. Bu durum yapılan birçok çalışmayla paraleldir $(2,10,20)$. Antibiyotiklerin bilinçsiz tüketilmesi ise ciddi bir halk sağlığı problemidir. Hem yeni antibiyotiklerin olmayışı, hem antibiyotiklere karşı direnç gelişmesi ve ciddi ekonomik etkiler göz önüne alındığında, bu konuda daha sıkı tedbirlerin alınmasının gerekliliği açıktır. Eczaneden reçetesiz alınan ilaçlarda antibiyotik oranının yapılacak yeni çalışmalarda çok daha düşük olması öngörülebilir; çünkü Türkiye'de artık reçetesiz eczaneden antibiyotik alınamamaktadır (21).

Basında 'doğal ürün', 'bitkisel ürün', 'gıda takviyesi', 'ilaç dışı tedavi ürünü', 'alternatif tedavi' adı altında birçok ürünün reklamı yapılmakta ve pazarlanmaktadır. Kişiler bu ürünleri doğal oldukları, hiç bir yan etkisinin olmayacağı düşüncesi, ilaç olarak görmedikleri gibi birçok nedenle kullanmaktadırlar. Hatta çoğu zaman hekimlerin bile ilaç kullanımı olarak görmedikleri için muayene sırasında bunların sorgulanmasını unuttukları ve yazdıkları ilaçlarla etkileşimleri için uyarmadıkları bilinmektedir (22). Türkiye'de yapılan birçok çalışmayla kıyaslandığında çalışmamızdaki bilinçsiz gıda takviyesi ve bitkisel ürün kullanımı oranının oldukça düşük olduğu söylenebilir $(23,24)$. Hastalık, ilaç, tedavi gibi profesyonel yaklaşım gerektiren bir durumun bilinçsizce uygulanmasının çok önemli sağıık sorunlarını beraberinde getireceği unutulmamalıdır. Bunların başında gerçek tedaviyi almada gecikme, beklenmeyen yan etkilerle başa çıkmaya çalışma, ciddi ilaç-gıda takviyesi etkileşimleri sayılabilir. Bazı durumlarda tıbbi endikasyon olarak vitamin ve mineral desteği almak gerekebilir; ancak çoğu zaman vitaminlere vücudumuzun eser miktarda ihtiyacı vardır ki bu miktarlar da gerekli besinlerin tüketilmesiyle sağlanabilir (25). Vitamin takviyesi kullanımı son yıllarda giderek yaygınlaşmaktadır. Bunun nedenleri; kişilerin vitaminleri ilaç olarak görmemeleri, yetersiz ve sağlıksız bir beslenme, uygunsuz diyet yapılması gibi nedenler olabilir. Ancak bazı vitamin ve minerallerin yüksek oranda kullanıldığında toksik etkileri olabileceğini bilmek gerekir. Türkiye'de yapılan bölgesel bir çalışmaya göre; sosyokültürel seviyenin yüksek olduğu kesimlerde vitamin kullanım oranının daha yüksek olduğu vurgulanmaktadır (26). Çalışmamızın diğer sonuçları da göz önüne alındığında, 'bilinçsiz vitamin desteği' oranları da beklendiği üzere diğer çalışmalardan daha düşük bulunmuştur. Bunun nedeni de yine sosyokültürel seviyenin düşüklügüyle daha iyi Aik davranışı sergileme paralelliği olabilir.

Aik tanımında yer alan 'tedavinin en uygun maliyette karşılanması' tabiriyle mevcut kaynakların korunması istenmektedir. Ancak bu çalışmada görüldüğü üzere hastaların yarısına yakını evlerinde kutusu dahi açılmadan ilaç atmakta ve hastaların yarısından fazlasının evlerinde yarım kalmış ya da hiç açılmamış ilaç bulunmaktadır. Bu çalışmaya benzer sonuçlar başka çalışmalarda da gösterilmiştir $(6,27)$. Bu durum Aik ekonomik ayağının zedelenmesine yol açmaktadır.

Yine bir başka önemli konu; ilaçları saklama koşullarıdır. Aslında üzerinde soğuk zincirle taşınmasına ya da saklanmasına dair herhangi bir uyarı olmayan ilaçların genellikle serin, güneş ışı̆̆ı görmeyen kuru bir ortamda saklanması gerekmektedir. Ancak çalışmadaki sonuçlara baktığımızda hastaların yarısından fazlası ilaçları buzdolabında saklamaktadır. Bu durumun ilaç güvenliği için belki bir avantajı olabilir ancak uygun bir saklama koşulu olup olmadığı tartışılmalıdır. Bir başka önemli konu da bireylerin tedavilerinden kalan ilaçları ne yaptıkları konusudur. Hastaların \%20'si çöpe attıklarını belirtmiştir. Bu hem kişi sağlığını hem de çevre sağlığını ilgilendiren önemli bir husustur. Ancak bu durum çoğu zaman sağlık profesyonellerinin bile zorlandığı bir durumdur (28). Düzenleyici otoriterlerin bu durumu düzeltmek için gereken çabayı göstermeleri gerekmektedir. Türkiye'de Tıbbi Atıkların Kontrolü Yönetmeliğine göre 
belediyeler atıkların toplanması ve nihai bertaraf edilmesinden sorumludur (29). Diğer yandan evde bulundurulan ilaçlar beraberinde tehlikeleri de getirmektedir; çocukların ilaca erişilebilirliklerinin artmasına bağlı zehirlenmeler, uygunsuz saklamaya bağlı etkinliğin azalması ya da yok olması söz konusu olabilmektedir (2).

AiK'nin bir başka önemli noktası uygun ilacı uygun sürede kullanma ilkesidir. Ancak çalışmamızın verilerine baktığımızda tedavisini hekimin önerdiği sürede tamamlamayanların oranı oldukça yüksektir. Özellikle antibiyotik kullanımında, tedavinin etkin sürede tamamlanmaması durumunda antibiyotik direnci ile karşı karşıya kalınır. Çalışmamızın verilerine göre hastaların yaklaşık yarısı ilacın kullanımı ve yan etkileriyle ilgili bilgileri ilaç prospektüsünden aldığını belirtmektedir. Ancak çoğu zaman ilaç prospektüsü anlaşılması zor bir dil kullanmaktadır. Oysaki hastaların çoğu ilaç yan etkisiyle ilgili bilgileri hekimlerinden almayı istemektedirler (2).

Hasta eczacı ilişkisine baktığımızda ise hastaların büyük bir kısmı reçetedeki ilaçları kontrol ettiklerini belirtiyorlar. Ancak artık Türkiye'de elektronik reçete (e reçete) oranının artmasından dolayı hastalar genellikle kendisine yazılan ilacı görememektedirler (30). Eşdeğer (jenerik) ilaç, orijinal ilaç ile aynı etken maddeyi, aynı dozlarda içeren, biyoeşdeğerliliği kanıtlanmış; ancak farklı firmalar tarafından üretilen ilaçlardır (31). Tanımdan da anlaşılacağı üzere eşdeğer ilaç hastalıkta aynı tedaviyi sağlayan ilaçtır; ancak hastaların çoğu eczacının önerdiği eşdeğer ilacı almak istemeyip fiyat farkını verip orijinal ilacı almak istemektedirler. Türkiye'de yapılan bir çalışmada hastaların, hekimlerin ve eczacıların büyük bir kısmı eşdeğer ilaçların orijinallerinden farklı etkide olduğunu düşünmektedir (32). Türkiye eşdeğer ilaç üreticisi bir ülkedir. Eşdeğer ilaç kullanımı ve üretimiyle ucuz ilaçlarla tedavi imkânına ulaşılabilinmektedir (9).

Kişilerin karşılaştıkları sağlık sorunlarındaki davranışları; sağlığı algılamaları, sağlık bilgi düzeyleri, öğrenim durumları, sağlık kurumlarından beklentileri gibi birçok faktörden etkilenmektedir (33). Bu çalışmadaki en önemli sosyodemografik değişkenlerden olan yaş ve cinsiyet akılcı ilaç kullanımı ile ilgili davranışları etkilemediği; ancak eğitim durumunun bazı davranışları etkilediği gösterilmiştir. Yapılan birçok çalışmada sosyodemografik özelliklerin Aik davranışı üzerindeki etkilerinde farklı sonuçlar elde edilmiştir (34, 15). Yaş, cinsiyet, eğitim ve diğer sosyodemografik özelliklerin akılcı ilaç kullanımı üzerindeki etkisinin topluma dayalı geniş katılımlı epidemiyolojik çalışmalarla değerlendirilmesi gerekmektedir (35).

Aik'nin sorumluluk sahibi taraflarından biri hastadır. Hastaların Aik'de 'katılımcı' olarak aktif görev almaları gerekmektedir. Hasta odaklı tedavilerin seçilmesiyle hasta tedaviye uyumunu arttıracak; artan hekim-hasta iletişimiyle Aik ilkelerine uygun bir tedavi planlanacaktır $(7,36)$. Ancak bunun doğru olarak yapılabilmesi için hastaların Aik bilgi ve davranışlarının ortaya bilimsel olarak koyulması gerekmektedir. Bu çalışmada, hastaların Aik konusundaki bilgi ve davranış durumlarının birçok parametre ile incelenmesi ve sorumluluk sahibi diğer tarafların da yanlışlarının hasta bakış açısıyla ortaya koyulması amaçlanmıştır.

Sonuç olarak; bu çalışma ile hastaların Aik ile ilişkili tutum ve davranışlarına bakıldığında, kendi kendini tedavi etme yaklaşımı konusunda iyi oldukları ancak ilaç muhafazası ve ilaç israfı konusunda eksikliklerinin olduğu söylenebilir. Bu eksikliklerin giderilmesi için topluma yönelik Aik konusunda bilinç oluşturulması için gerekli eğitimlerin verilmesi ve önlemlerin alınması önerilmektedir.

Bilgilendirilmiş Onam: Katılımcılardan yazılı onam alınmıştır.

Çıkar Çatışması: Yazarlar çıkar çatışması beyan etmemişlerdir. 
Finansal Destek: Yazarlar finansal destek beyan etmemişlerdir.

\section{KAYNAKLAR}

1. WHO. Conference of experts on the rational use of drugs. Nairobi, Kenya. 1985; 25-29.

2. Mollahaliloğlu $S$, Özgülcü $S$, Alkan A, Öncül HG. Toplumun akılcı ilaç kullanımına bakışı. Türkiye Cumhuriyeti Sağlık Bakanlığı, Refik Saydam Hıfzıssıhha Merkezi Başkanlığı, Hıfzıssıhha Mektebi Müdürlüğü Ankara. 2011.

3. Karatas Y, Dinler B, Erdogdu T, Ertug P, Seydaoglu G. Evaluation of drug use attitudes of patient and its relatives attending to Cukurova University Medical faculty Balcali Hospital. Cukurova Medical Journal 2012; 37(1): 1-8.

4. WHO. Adherence to long-term therapies: evidence for action: World Health Organization; 2003.

5. Goossens $H$, Ferech $M$, Vander Stichele R, Elseviers $M$, ESAC Project Group. Outpatient antibiotic use in Europe and association with resistance: a crossnational database study. The Lancet 2005; 365(9459): 579-87.

6. Calikoglu E, Koycegiz E, Kosan Z, Aras A. Rational drug use and prescribing behavior of family physicians in Erzurum, Turkey. Niger J Pract 2019; 22: 626- 632.

7. WHO. The pursuit of responsible use of medicines: sharing and learning from country experiences. World Health Organization; 2012.

8. Sağlık Bakanlığı. Sağlık İstatistikleri Yıllığı 2019. Türkiye Cumhuriyeti Sağlık Bakanlığı Sağlık Bilgi Sistemleri Genel Müdürlüğü, Ankara. 2021.

9. Sanayi Bakanlığı, Ticaret Bakanlığı. Türkiye Illaç Sektörü Strateji Belgesi ve Eylem Planı 2015-2018.

10. Okyay RA, Erdoğan A. Self-medication practices and rational drug use habits among university students: a cross-sectional study from Kahramanmaraş, Turkey. Peer J. 2017; 5: e3990.

11. WHO. Guidelines for the Regu latory Assessment of Medicinal Products for use in Self-Medication. World Health Organization; Geneva 2000.

12. Nayir T, Okyay RA, Yesilyurt H, Akbaba M, Nazhcan E, Acik Y, Akkus HI. Assessment of rational use of drugs and self-medication in Turkey: a pilot study from Elazıg and its suburbs. Pak J Pharm Sci 2016; 29(4 Suppl): 1429-35.

13. Baybek $H$, Bulut $D$, Çakır A. Muğla Üniversitesi idari personelinin ilaç kullanma alışkanlıklarının belirlenmesi. Muğla Üniversitesi Sosyal Bilimler Enstitüsü Dergisi 2005; 15: 53-67.

14. Carrasco-Garrido P, Jiménez-García R, Barrera VH, Gil de Miguel A. Predictive factors of self-medicated drug use among the Spanish adult population. Pharmacoepidemiol Drug Saf 2008; 17(2): 193-9.
15. Uskun E, Uskun SB, Öztürk $M$, Kişioğlu AN. Sağlık ocağına başvuru öncesi ilaç kullanımı. STEP 2004; 13(12): 451-54.

16. Kartal H, Özerdoğan Ö, Çan G, Bakar C. Bir tıp fakültesinde öğrencilerin kendi kendine ilaç kullanma durumları ve ilişkili faktörlerin incelenmesi, Çanakkale, Türkiye. Troia Med J 2021; 2(1): 14-20.

17. Başaran $M$, Küçük Ö. Dental ağrı geçmişi olan hastaların akılcı ılaç kullanımına yönelik bilgi ve davranışlarının değerlendirilmesi. Selcuk Dent J, 2021; 8: 8-14.

18. Yaramış Mi, Ulupınar S. Bir aile sağlığı merkezine kayıtlı bireylerin akılcı ilaç kullanım davranışları. Ordu University J Nurs Stud 2021; 4(1): 10-20.

19. Ibrahim NK, Alamoudi BM, Baamer WO, Al-Raddadi RM. Self-medication with analgesics among medical students and interns in King Abdulaziz University, Jeddah, Saudi Arabia. Pak J Med Sc 2015; 31(1): 14.

20. Coşkun N, Sungur M, Aydın M, Solmaz C, Turhan E, Dizman B , Çaput F, Yıldırım i . Batı Karadeniz Bölgesinde Bir Üniversite Hastanesine Başvuran Hasta ve Hasta Yakınlarının Akılcı Ilaç Kullanımına Yönelik Bilgi ve Davranışlarının Değerlendirilmesi. DÜ Sağlık Bil Enst Derg. 2021; 11(2): 206-213.

21. Sağıık Bakanlığı. Akılcı Illaç Kullanımı Ulusal Eylem Planı 2014-2017.

22. Basaran NF, Akici A. Patients' experience and perspectives on the rational use of drugs in Turkey: a survey study. Patient Prefer Adherence 2012; 6: 719.

23. Kaner G, Karaalp C, Seremet-Kürklü N. Üniversite öğrencileri ve ailelerinde bitkisel ürün kullanım sıklığının ve bitkisel ürün kullanımını etkileyen faktörlerin belirlenmesi. Turk Hij Den Biyol Derg 2016; 74(1): 37-54.

24. Koçtürk OM, Kalafatçılar ÖA, Özbilgin N, Atabay $H$. Türkiye'de bitkisel ilaçlara bakış. Ege Üniv. Ziraat Fak. Derg. 2009; 46(3): 209-14.

25. Şerife GÖ, Kılıçarslan A. Vitaminlerin yaşamımızdaki yeri nedir, ne olmalıdır? İç Hastalıkları Dergisi 2012; 19 : 139-143.

26. Coşkun F, Turhan H. İstanbul'da vitamin kullanım alışkanlıkları ve bu alışkanlıkları etkileyen faktörler üzerine bir araştırma. Marmara Ecza Derg 2010; 14(1): 21-8.

27. Yazicioglu B, Yardan ED. Rational drug use in elderly patients in a primary care center. JPMA 2021; 71(5): 1353-1356.

28. Bek N, Bek A. Sağlık Çalışanları Sude Atık Bilgisi Üzerine Bir Durum Çalışması. TroyAcademy. 2021; 6(2): 395410.

29. Tıbbi Atıkların Kontrolü Yönetmeliği. Resmi Gazete Sayısı: 29959. Resmi Gazete Tarihi. 2017; 25:2017.

30. Kılıç T, Bostan S, Şahin G. Example of lean management in the health sector; e-prescription application. International Journal of Health Management and 
Tourism. 2016; 1(1): 29-40.

31. İnal A, Erenmemişoğlu A. Klinik ilaç araştırmalarından biyoyararlanım/biyoeşdeğerlik çalışmaları. Türkiye Klinikleri Farmakoloji Klinik Araştırmaları Özel Sayısı 2016; 4(2): 26-32.

32. Toklu HZ, Dülger GA, Hıdıroğlu S, Akici A, Yetim A, Gannemoğlu HM, Güneş $H$. Knowledge and attitudes of the pharmacists, prescribers and patients towards generic drug use in Istanbul-Turkey. Pharm Pract (Granada) 2012; 10(4): 199-206.

33. Illhan MN, Aydemir Ö, Çakır M, Aycan S. Akılcı olmayan ilaç kullanım davranışları: Ankara'da üç ilçe örneği. Turk
J Public Health 2014; 12(3): 188-200.

34. Yapıcı G, Balıkçı S, Uğur Ö. Birinci basamak sağlık kuruluşuna başvuranların ilaç kullanımı konusundaki tutum ve davranışları. Dicle Med J 2011; 38(4): 458465.

35. Ekenler Ş, Kocaoğlu D. Bireylerin akılcı ilaç kullanımıyla ilgili bilgi ve uygulamaları. Journal of Hacettepe University Faculty of Nursing 2016; 3(3): 44-55.

36. Tichelaar J, Richir MC, Garner S, Hogerzeil H, De Vries TP. WHO guide to good prescribing is 25 years old: quo vadis? Eur J Clin Pharmacol 2020; 76:507-513.

Table 1. Akılcı olmayan ilaç kullanımı (AOIK)

- Çoklu ilaç kullanımı (polifarmasi)

- Iilaçların gereksiz ve aşırı kullanımı

- Ilaç kullanımında özensiz davranılması (uygulama yolu, süresi, dozu...)

- Uygun olmayan farmasötik şekillerin kullanılması

- Gereksiz yere enjeksiyon preparatı yazılması/kullanılması

- Temel ilaç listelerine veya güncel rehberlere uygun olmayan ilaçların reçetelere yazııması

- Kişilerin kendi kendini tedavi etme yaklaşımı

- $\quad$ Piyasaya yeni çıkan ilaçların uygunsuz tercihi

- Özel hasta gruplarına (çocuk, yaşı, hamile, kronik hastalığı olanlar) uygunsuz ilaç yazılması/kullanılması;

- Gereksiz yere pahalı ilaçların yazılması/kullanııması

- Gereksiz yere antibiyotik yazılması/kullanılması

- Gereksiz ve uygunsuz vitamin kullanımı

- Bilinçsiz gıda takviyesi ve bitkisel ürünlerin kullanımı

- $\quad$ ilaç-ilaç etkileşimleri ve besin-ilaç etkileşimlerinin ihmal edilmesi

- Tedavileri konusunda hastalara yeterli bilginin verilmemesi

- Yazılan reçetelerin gereken tüm doğru bilgileri içermesine özen gösterilmemesi

- Eczacıların reçete karşılama, ilaç verme ve hastayı bilgilendirme konusunda yeterli davranış sergilememesi

- Sağık personelinin ilaç uygulama hatası yapması

- Yanlış ilaç kullanımını kolaylaştıran ilaç üretimi ve dağıtımı kaynaklı çeşitli altyapı sorunlarının bulunması 
Oral S.

Table 2. Sosyodemografik özellikler

$\mathbf{N}$

$\%$

\section{Cinsiyet}

$\begin{array}{lll}\text { Kadın } & 93 & 61.2 \\ \text { Erkek } & 59 & 38.8\end{array}$

\section{Eğitim}

$\begin{array}{rcc}\text { Okuma yazma yok } & 13 & 8.7 \\ \text { illköğretim } & 87 & 58.4 \\ \text { Lise } & 38 & 25.5 \\ \text { Yüksek öğretim } & 11 & 7.4 \\ \text { Yüksek lisans/Doktora } & 0 & 0\end{array}$

Table 3. Hastaların hastalık durumundaki davranışları

\begin{tabular}{|c|c|c|}
\hline Hastalık durumunda ne yaparsınız? & $\mathbf{n}$ & $\%$ \\
\hline Hekime danışırım & 131 & 91.6 \\
\hline Eczacıya danışırım & 7 & 4.9 \\
\hline Hemşire, sağlık memuru veya sağlık personeline danışırım & 12 & 8.4 \\
\hline Tanıdık / komşu / akrabaya danışırım & 1 & 7.0 \\
\hline Bitkisel tedavi yöntemlerini denerim & 5 & 3.5 \\
\hline Evde bulunan ilaçlarla tedavi olmaya çalışııım & 6 & 4.2 \\
\hline Daha önce benim hastalığıma benzer rahatsızlık geçirmiş olanlara sorarım & 1 & 0.7 \\
\hline Diğer & - & - \\
\hline
\end{tabular}


Grip, nezle, soğuk algınlığı gibi şikayetleriniz üzerine muayene olmadan, kendi başınıza antibiyotik kullanır mısınız?

$\begin{array}{rcc}\text { Evet; kullanırım } & 33 & 23.2 \\ \text { Hayır; muayene olmadan kullanmam } & 109 & 76.8\end{array}$

Hastalıkta hekime muayene olmadan eczaneden ilaç alır mısınız?

$\begin{array}{rcc}\text { Evet } & 26 & 17.7 \\ \text { Hayır } & 122 & 82.9\end{array}$

Komşularınız ve/veya yakınlarınızın tavsiyesi ile ilaç kullanır mısınız?

$\begin{array}{rcc}\text { Evet } & 13 & 9.1 \\ \text { Hayır } & 130 & 90.9\end{array}$

Yakınlarınızdan tavsiye aldığınız ilaçları doktorunuzdan reçete etmesini ister misiniz?

$\begin{array}{rcc}\text { Evet } & 32 & 22.5 \\ \text { Hayır } & 110 & 77.5\end{array}$

Benzer şikayetleri olan tanıdıklarınıza ilaç tavsiyesinde bulunur musunuz?

Gerekli olabileceği düşüncesiyle hasta olmadan ilaç yazdırır mısınız?

$\begin{array}{rcc}\text { Evet } & 15 & 10.6 \\ \text { Hayır } & 126 & 89.4\end{array}$

Gerekli olabileceği düşüncesiyle hasta olmadan ilaç satın alıp evde bulundurur musunuz?

Ağrı kesici ihityacınız olduğunda ilacı nasıl temin eder misiniz?

Hayır $\quad 75$

$$
\text { Reçete ile eczaneden }
$$

Basında (tv, radyo, gazete, vb.) reklamı yapılan ürünleri tedavi amacıyla kullanır misınız?

$\begin{array}{rcc}\text { Direk kullanırım } & 6 & 4.1 \\ \text { Hekime danışarak kullanırım } & 22 & 15.1 \\ \text { Eczacıya danışarak kullanırım } & 7 & 4.8 \\ \text { Kullanan tanıdığıma, komşuma sorar kullanırım } & 2 & 1.4 \\ \text { Kullanmam } & 114 & 78.1\end{array}$

Düzenli vitamin, mineral desteği alır mısınız?

\begin{tabular}{rcc} 
Her gün & 8 & 5.6 \\
Haftada 2-3 kez & 13 & 9.1 \\
Ayda 3-4 kez & 9 & 6.3 \\
Hayı̆ kullanmam & 19 & 13.3 \\
\hline
\end{tabular}


Table 5. Evdeki ilaçlar

Evinizde ilaç kullanırken son kullanma tarhini kontrol ediyor musunuz?

$\begin{array}{ccc}\text { Evet } & 140 & 94.0 \\ \text { Hayır } & 9 & 6.0\end{array}$

Evinizde her yıl ortalama kaç kutu ilaç; kutusu bile açılmadan, son kullanım tarihi geçtiği için atılmaktadır?

Alle bireylerinin tedavi sonrası arta kalan ilaçlarını ne yaparsınız?

Gerektiği zaman kullanmak üzere saklarım $\quad 44 \quad 28.3$

Sağlık kuruluşuna veririm $\quad 53 \quad 34.2$

$\begin{array}{lll}\text { Eczaneye veririm } & 17 & 10.9\end{array}$

İsteyen tanıdıklara veririm $\quad 1 \quad 1.0$

Çöpe atarım $\quad 31 \quad 20.0$

Tuvalete atarım

$\begin{array}{lll}\text { Diğer } & 9 & 5.8\end{array}$

Evinizde hiç kullanılmamış veya yarım kalmış ortalama kaç kutu ilaç vardır?

$\begin{array}{rcc}\text { Hiç yok } & 54 & 36.5 \\ 1-5 & 63 & 42.6 \\ 6-10 & 17 & 11.5 \\ 10^{\prime} \text { dan fazla } & 14 & 9.5\end{array}$

Üzerinde saklama koşulları ile ilgili herhangi bir uyarı bulunmayan ilaçları nerede saklıyorsunuz?

$\begin{array}{rcc}\text { Buzdolabında } & 75 & 51.4 \\ \text { Buzlukta / Derin dondurucuda } & 4 & 2.7 \\ \text { klığında, serin ve kuru bir yerde } & 67 & 45.9\end{array}$

Evinizde bulunan ilaç, buzdolabında saklanması gerekiyorsa buzdolabının hangi bölümünde saklarsınız?

$\begin{array}{rcc}\text { Buzdolabının kapağında } & 97 & 67.8 \\ \text { Buzdolabının rafında } & 45 & 31.5 \\ \text { kta / Derin dondurucuda } & 1 & 0.7\end{array}$

Buzlukta / Derin dondurucuda $\quad 1 \quad 0.7$

Evde ilaç bulunduruyorsanız; bunları tekrar kullanırken nelere dikkat edersiniz?

Hastalığa uygunluğuna $\quad 99 \quad 69.2$

Son kullanma tarihinin dolmamış olmasına $\quad 112 \quad 78.3$

Şurup, süspansiyon, göz damlası gibi ilaç formlarının kullanma talimatında belirtilen süreleri $\quad 62 \quad 43.4$

aşmamışolmasına
28

$\begin{array}{rcc}\text { Ambalajının bozulmamıs olmasına } & 28 & 19.6 \\ \text { Hiçbirine dikkat etmem } & 2 & 1.4\end{array}$

Evde bulundurmuş olduğunuz ilaçları tekrar kullanmak istediğinize kimden bilgi alırsınız?

Hekim $\quad 76 \quad 52.8$

Eczacl $\quad 41 \quad 28.5$

Hemşire, sağlık görevlisi $\quad 10 \quad 6.9$

Tanıdık / Komşu / Akraba $\quad 2 \quad 1.4$

Daha önce kullandığım için kimseden bilgi almam $\quad 28 \quad 19.4$

$\begin{array}{lll}\text { Diğer } & 1 & 0.7\end{array}$ 
Hekime giderken daha önce kullanmış olduğunuz ilaçlar ve varsa hastalıklarınıza ait ilaç raporlarınız hakkında hekimi bilgilendirir misiniz?

Evet

Besin veya ilaç alerjiniz var ise; muayene sırasında hekimi ve ilgili sağlık personelini

bilgilendirir misiniz?

$\begin{array}{ccc}\text { Evet, bilgilendiririm } & 133 & 91.1 \\ \text { Hayır, bilgilendirmem } & 3 & 2.1 \\ \text { Sorarsa bilgilendiririm } & 11 & 7.5\end{array}$

Hekimin vermiş olduğu ilaçları ne şekilde kullanırsınız?

$\begin{array}{rcc}\begin{array}{r}\text { Illaç bitene kadar kullanırım } \\ \text { Şikayetim geçene kadar kullanırım }\end{array} & 39 & 34.3 \\ \text { Hekim önerdiği süre kullanırım } & 62 & 43.4 \\ \text { Diğer } & 1 & 0.7\end{array}$

Hekiminiz tedavisini yapınca kontrole çağırırsa gider misiniz?

\begin{tabular}{|c|c|}
\hline Evet, şikayetlerim geçmezse giderim & 66 \\
\hline Evet, şikayetlerim geçse de giderim & 83 \\
\hline şikayetlerim geçince gerek duy & 4 \\
\hline
\end{tabular}

Sizce ilaçları uygulama şekli tedavi başarısında etkili midir?

Evet, iğne olursa daha iyi tedavi olurum

İğneden korkarım, ağızdan alınan ilaçları tercih ederim 
Reçete ile ilaç alırken, reçetede yazan ilaç olup olmadığını kontrol eder misiniz?

$\begin{array}{ccc}\text { Evet } & 109 & 75.2 \\ \text { Hayır } & 36 & 24.8\end{array}$

Eczanede reçetede yazılandan farklı olarak, eczacının önerdiği eşdeğer ilacı kabul eder misiniz?

$\begin{array}{lll}\text { Evet } & 47 & 32.2 \\ \text { Hayır } & 99 & 67.8\end{array}$

Eczacınız, aldığınız ilacın nasıl kullanılacağı konusunda bilgi verip doğru anlaşıldığına emin olana kadar anlatıyor mu?

$\begin{array}{lll}\text { Evet } & 130 & 90.3 \\ \text { Hayır } & 14 & 9.7\end{array}$

Table 8. İlaç yan etkisine yaklaşım

n

İlacın kullanımı ile ilgili bilgileri ve olası yan etkileri nereden öğrenirsiniz?

$\begin{array}{rcc}\text { Hekim } & 52 & 35.6 \\ \text { Eczacı } & 30 & 20.5 \\ \text { Yardımcı sağlık personeli (Hemşire, ebe, sağlık memuru, vb.) } & 9 & 6.2 \\ \text { İlacın prospektüsü } & 68 & 46.6 \\ \text { Internet } & 4 & 2.7\end{array}$

ilacın yan etkileri ile karşılaşırsanız nasıl davranırsınız?

$\begin{array}{rccc}\text { Hekime başvururum } & 126 & 83.4 \\ \text { Eczacıya başvururum } & 15 & 10.3 \\ \text { Yardımcı sağlık personeli (Hemşire, ebe, sağlık memuru, vb.) başvururum } & 4 & 2.8 \\ \text { Kendim çözüm ararım } & 3 & 2.1 \\ \text { Hiçbirşey yapmam } & 2 & 1.4\end{array}$

Ilaçlarla birlikte tüketmemeniz gereken yiyecek ve içecekler ile ilgili bilgilendirme yapılıyor mu?

$\begin{array}{ccc}\text { Evet } & 89 & 63.1 \\ \text { Hayır } & 52 & 36.9\end{array}$


Table 9. Sosyodemografik özelliklerin akııı ilaç kullanımına etkileri

\begin{tabular}{|c|c|c|c|c|c|c|c|c|c|c|c|c|c|c|c|c|c|c|c|c|c|c|c|c|c|}
\hline & \multicolumn{11}{|c|}{ Yas } & \multicolumn{5}{|c|}{ Cinsiyet } & \multicolumn{9}{|c|}{ Eğitim Durumu } \\
\hline & \multicolumn{2}{|c|}{$\begin{array}{c}24 \text { yas ve } \\
\text { altı }\end{array}$} & \multicolumn{2}{|c|}{$\begin{array}{c}24-36 \text { yas } \\
\text { arası }\end{array}$} & \multicolumn{2}{|c|}{$\begin{array}{l}36-48 \text { yas } \\
\text { arası }\end{array}$} & \multicolumn{2}{|c|}{$\begin{array}{l}48-60 \text { yaş } \\
\text { arası }\end{array}$} & \multicolumn{2}{|c|}{$\begin{array}{l}60 \text { yaş ve } \\
\text { üzeri }\end{array}$} & \multirow[t]{2}{*}{$P$} & \multicolumn{2}{|c|}{ Erkek } & \multicolumn{2}{|c|}{ Kadin } & \multirow[t]{2}{*}{$p$} & \multicolumn{2}{|c|}{$\begin{array}{l}\text { Okuma } \\
\text { yazma } \\
\text { bilmiyor }\end{array}$} & \multicolumn{2}{|c|}{ ilköğretim } & \multicolumn{2}{|c|}{ Lise } & \multicolumn{2}{|c|}{ Yükseköğrenim } & \multirow[t]{2}{*}{$P$} \\
\hline & $n$ & $\%$ & $\mathrm{n}$ & $\%$ & $\mathrm{n}$ & $\%$ & $\mathrm{n}$ & $\%$ & $\mathrm{n}$ & $\%$ & & $\mathrm{n}$ & $\%$ & $\mathrm{n}$ & $\%$ & & $\mathrm{n}$ & $\%$ & $\mathrm{n}$ & $\%$ & $\mathrm{n}$ & $\%$ & $\mathrm{n}$ & $\%$ & \\
\hline \multicolumn{26}{|l|}{$\begin{array}{l}\text { Grip, nezle, soğuk alginliğı gibi sikayetlerinizz } \\
\text { üzerine muayene olmadan, kendi başııza } \\
\text { antibiyotik kullanır mısını? }\end{array}$} \\
\hline Evet & 3 & 10.3 & 10 & 34.5 & 5 & 17.2 & 6 & 20.7 & 5 & 17.2 & 0.782 & 18 & 54.5 & 15 & 45.5 & 0.419 & 6 & 18.8 & 11 & 34.4 & 12 & 37.5 & 3 & 9.4 & $0.031^{*}$ \\
\hline Hayır & 14 & 12.8 & 25 & 22.9 & 20 & 18.3 & 24 & 22.0 & 26 & 23.9 & & 68 & 62.4 & 41 & 37.6 & & 8 & 7.4 & 68 & 63.0 & 24 & 22.2 & 8 & 7.4 & \\
\hline \multicolumn{26}{|l|}{ Hastallk durumunda ne yaparsınz?? } \\
\hline Hekime başvururum & 16 & 12.5 & 33 & 25.8 & 22 & 17.2 & 26 & 20.3 & 31 & 24.2 & 0.294 & 80 & 60.6 & 52 & 39.4 & 0.806 & 12 & 9.2 & 73 & 56.2 & 34 & 26.2 & 11 & 8.5 & 0.735 \\
\hline Eczacıya danışıırm. & 0 & 0.0 & 0 & 0.0 & 0 & 0.0 & 1 & 50.0 & 1 & 50.0 & & 1 & 50.0 & 1 & 50.0 & & 0 & 0.0 & 2 & 100.0 & 0 & 0.0 & 0 & 0.0 & \\
\hline $\begin{array}{l}\text { Hemșire, sağlık memuru veya sağık personeline } \\
\text { danııırirm. }\end{array}$ & 1 & 20.0 & 0 & 0.0 & 3 & 60.0 & 1 & 20.0 & 0 & 0.0 & & 4 & 80.0 & 1 & 20.0 & & 1 & 33.3 & 1 & 33.3 & 1 & 33.3 & 0 & 0.0 & \\
\hline \multicolumn{26}{|l|}{$\begin{array}{l}\text { Hastalkta hekime muayene olmadan ilaç allip. } \\
\text { baslar missin? }\end{array}$} \\
\hline Evet & 4 & 17.4 & 5 & 21.7 & 3 & 13.0 & 3 & 13.0 & 8 & 34.8 & 0.587 & 14 & 53.8 & 12 & 46.2 & 0.441 & 2 & 7.7 & 14 & 53.8 & 8 & 30.8 & 2 & 7.7 & 0.909 \\
\hline \multirow{2}{*}{\multicolumn{26}{|c|}{ Hasta olmadan ilac yazdrrrr misiniz? }} \\
\hline & & & & & & & & & & & & & & & & & & & & & & & & & \\
\hline Evet & 2 & 15.4 & 2 & 15.4 & 1 & 7.7 & 3 & 23.1 & 5 & 38.5 & 0.574 & 7 & 46.7 & 8 & 53.3 & 0.205 & 2 & 13.3 & 7 & 46.7 & 6 & 40.0 & 0 & 0.0 & 0.266 \\
\hline Hayır & 15 & 12.0 & 31 & 24.8 & 24 & 19.2 & 28 & 22.4 & 27 & 21.6 & & 80 & 63.5 & 46 & 36.5 & & 12 & 9.6 & 71 & 56.8 & 31 & 24.8 & 11 & 8.8 & \\
\hline \multicolumn{26}{|l|}{$\begin{array}{l}\text { Hasta olmadan ilac satin alip evde bulundurur } \\
\text { musunuz? }\end{array}$} \\
\hline 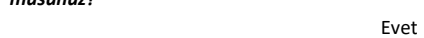 & 1 & 9.1 & 3 & 27.3 & 2 & 18.2 & 3 & 27.3 & 2 & 18.2 & 0.959 & 8 & 61.5 & 5 & 38.5 & 0.989 & 0 & 0.0 & 5 & 38.5 & 8 & 61.5 & 0 & 0.0 & $0.025 *$ \\
\hline Hayir & 11 & 15.1 & 19 & 26.0 & 11 & 15.1 & 15 & 20.5 & 17 & 23.3 & & 46 & 61.3 & 29 & 38.7 & & 4 & 5.5 & 48 & 65.8 & 16 & 21.9 & 5 & 6.8 & \\
\hline $\begin{array}{l}\text { Hekiminiz tedavisini yapınca kontrole çă̆rrısa } \\
\text { gider misiniz? }\end{array}$ & & & & & & & & & & & & & & & & & & & & & & & & & \\
\hline Evet, şkayetlerim geçmezse giderim & 9 & 14.5 & 14 & 22.6 & 13 & 21.0 & 12 & 19.4 & 14 & 22.6 & 0.828 & 41 & 62.1 & 25 & 37.9 & 0.339 & 8 & 12.5 & 35 & 54.7 & 18 & 28.1 & 3 & 4.7 & 0.707 \\
\hline Evet, şikayetlerim geçse de giderim & 10 & 13.0 & 18 & 23.4 & 12 & 15.6 & 18 & 23.4 & 19 & 24.7 & & 47 & 61.0 & 30 & 39.0 & & 7 & 9.1 & 43 & 55.8 & 19 & 24.7 & 8 & 10.4 & \\
\hline Hayır, şikayetlerim geçince gerek duymam & 0 & 0.0 & 1 & 25.0 & 0 & 0.0 & 1 & 25.0 & 2 & 50.0 & & 1 & 25.0 & 3 & 75.0 & & 0 & 0.0 & 3 & 75.0 & 1 & 25.0 & 0 & 0.0 & \\
\hline Düzenli vitamin, mineral desteği alır mısınız? & & & & & & & & & & & & & & & & & & & & & & & & & \\
\hline Her gün & 1 & 12.5 & 2 & 25.0 & 1 & 12.5 & 2 & 25.0 & 2 & 25.0 & 0.580 & 5 & 55.6 & 4 & 44.4 & 0.619 & 0 & 0.0 & 5 & 55.6 & 4 & 44.4 & 0 & 0.0 & 0.065 \\
\hline Haftada 2-3 kez & 4 & 36.4 & 1 & 9.1 & 1 & 9.1 & 3 & 27.3 & 2 & 18.2 & & 9 & 75.0 & 3 & 25.0 & & 3 & 25.0 & 8 & 66.7 & 0 & 0.0 & 1 & 8.3 & \\
\hline Ayda 3-4 kez & 3 & 37.5 & 1 & 12.5 & 2 & 25.0 & 1 & 12.5 & 1 & 12.5 & & 6 & 66.7 & 3 & 33.3 & & 1 & 12.5 & 2 & 25.0 & 4 & 50.0 & 1 & 12.5 & \\
\hline Sadece kendimi kötü hissettiğimde kullanırım & 2 & 12.5 & 4 & 25.0 & 3 & 18.8 & 2 & 12.5 & 5 & 31.3 & & 8 & 47.1 & 9 & 52.9 & & 0 & 0.0 & 12 & 70.6 & 4 & 23.5 & 1 & 5.9 & \\
\hline Hayir kullanmam & 7 & 7.3 & 27 & 28.1 & 19 & 19.8 & 22 & 22.9 & 21 & 21.9 & & 59 & 61.5 & 37 & 38.5 & & 10 & 10.5 & 52 & 54.7 & 25 & 26.3 & 8 & 8.4 & \\
\hline
\end{tabular}

${ }^{*} \mathrm{p}<0.05$; Olabilirlik Oran Testi (Likelihood ratio test) uygulanmistır. 


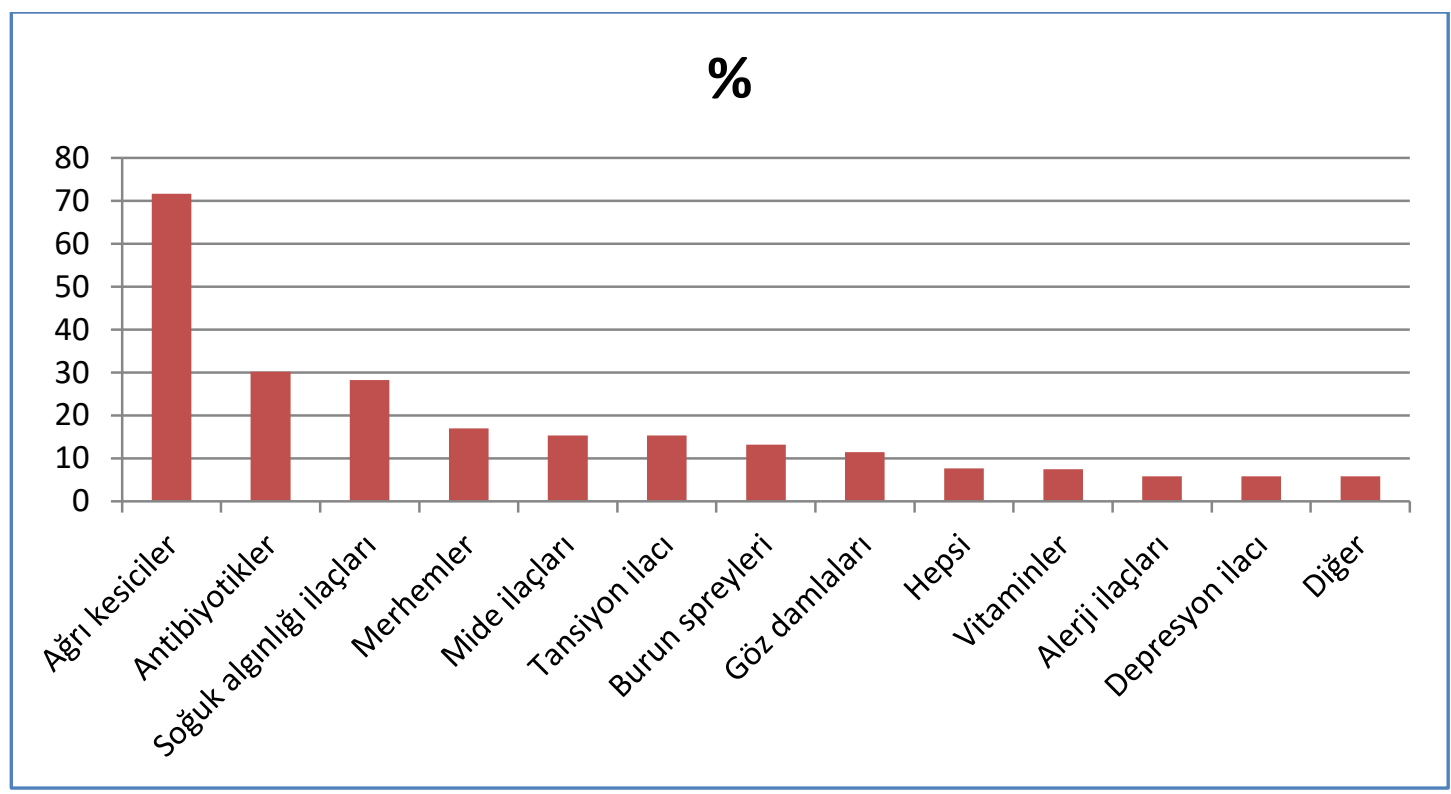

Şekil 1. Kendi kendine başlanan ilaçlar 